\title{
Rechargeable aqueous lithium-air batteries with an auxiliary electrode for the oxygen evolution
}

\author{
S. Sunahiro ${ }^{\mathrm{a}}$. M. Matsui ${ }^{\mathrm{a}, \mathrm{b}}$, Y. Takeda ${ }^{\mathrm{a}}$, O. Yamamoto ${ }^{\mathrm{a},{ }^{*}}$, and N. Imanishi ${ }^{\mathrm{a}}$ \\ ${ }^{a}$ Graduate School of Engineering, Mie University, Tsu, Mie, 514-8507, Japan \\ ${ }^{b} J S T$, PRESTO, 4-1-8 Honcho, Kawaguchi, Saitama, 332-0012, Japan
}

\begin{abstract}
A rechargeable aqueous lithium-air cell with a third auxiliary electrode for the oxygen evolution reaction was developed. The cell consists of a lithium metal anode, a lithium conducting solid electrolyte of $\mathrm{Li}_{1+x+y} \mathrm{Al}_{\mathrm{x}}(\mathrm{Ti}, \mathrm{Ge})_{2-\mathrm{x}} \mathrm{Si}_{\mathrm{y}} \mathrm{P}_{3-\mathrm{y}} \mathrm{O}_{12}$, a carbon black oxygen reduction air electrode, a $\mathrm{RuO}_{2}$ oxygen evolution electrode, and a saturated aqueous solution of $\mathrm{LiOH}$ with $10 \mathrm{M} \mathrm{LiCl}$. The cell was successfully operated for several cycles at $0.64 \mathrm{~mA} \mathrm{~cm}^{-2}$ and $25^{\circ} \mathrm{C}$ under air, where the capacity of air electrode was $2000 \mathrm{mAh}$ $\mathrm{g}_{\text {carbon }}{ }^{-1}$. The cell performance was degraded gradually by cycling under open air. The degradation was reduced under $\mathrm{CO}_{2}-$ free air and pure oxygen. The specific energy density was calculated to be $810 \mathrm{Wh} \mathrm{kg}^{-1}$ from the weight of water, lithium, oxygen, and carbon in the air electrode
\end{abstract}

\section{Introduction}

Rechargeable lithium-air batteries have potential application as a power source for electric vehicles $(\mathrm{EV})$, because of their high energy density and lower material cost than conventional lithium-ion batteries. At present, two types of rechargeable lithium-air batteries have been developed; non-aqueous [1] and aqueous systems [2]. The specific energy density of the non-aqueous system $\left(3460 \mathrm{Wh} \mathrm{kg}^{-1}\right)$ is higher than that of the aqueous system (1910 $\mathrm{Wh} \mathrm{kg}^{-1}$ ). However, the non-aqueous system has serious problems to be solved, such as the decomposition of aprotic electrolytes [3], high overpotentials for the oxygen reduction and evolution reactions [4], protection of the lithium metal electrode from water and carbon dioxide in the air [5], and carbon decomposition of the air electrode during the charge process [6]. These problems observed for the non-aqueous system could be removed for the aqueous system. One of the major advantages of the aqueous lithium-air system is that the reaction product of $\mathrm{LiOH}$ is soluble in the electrolyte. Protection of the lithium metal electrode from water is the most critical point for the aqueous system. The aqueous lithium-air battery system was proposed by Visco et al. [7] using a water stable NASICON-type lithium

*Corresponding author. Tel: +81-59-231-9420

E-mail: Yamamoto@chem.mie-u.ac.jp (O.Yamamoto) 
conducting solid electrolyte of $\mathrm{Li}_{1+x+y} \mathrm{Al}_{\mathrm{x}}(\mathrm{Ti}, \mathrm{Ge})_{2-\mathrm{x}} \mathrm{Si}_{\mathrm{y}} \mathrm{P}_{3-\mathrm{y}} \mathrm{O}_{12}$ (LATP). The water permeation-free dense LATP plate has a lithium ion conductivity of $1 \times 10^{-4} \mathrm{~S} \mathrm{~cm}^{-1}$ at room temperature. However, LATP is unstable in contact with lithium metal $[8,9]$. Visco et al. [7] and Zhang et al. [10] used $\mathrm{Li}_{3} \mathrm{~N}$ and polyethylene oxide (PEO) with $\mathrm{Li}\left(\mathrm{CF}_{3} \mathrm{SO}_{2}\right)_{2} \mathrm{~N}$ (LiTFSI) as the interlayer between lithium metal and LATP, respectively. $\mathrm{Li}_{3} \mathrm{~N}$ and the polymer electrolyte are stable in contact with lithium metal, but unstable in aqueous solutions. Zhou et al. also reported the use of an organic electrolyte between lithium metal and LATP [11].

Rechargeable lithium-air batteries require a bifunctional air electrode for the oxygen reduction (ORR) and oxygen evolution reactions (OER). The development of rechargeable zinc-air batteries with a concentrated alkaline solution began in the middle of 1960s [12]. There have been many reports on ORR in alkaline solution; however, there are few reports on OER [13]. When an air electrode is used for oxygen evolution, it is exposed to a highly corrosive potential. The bifunctional electrodes for rechargeable zinc-air batteries have very complicated multilayer designs and compositions, but all of them have insufficient lifetime of the oxygen reduction catalyst at high oxygen reduction potentials (ca. $2.1 \mathrm{~V}$ vs. $\mathrm{Zn} / \mathrm{Zn}^{2+}$ ). Arai et al. [14] examined a carbon black electrode for ORR and OER in aqueous $8 \mathrm{M} \mathrm{KOH}$ and observed electrode deterioration during OER, which they claimed due to a loss of the electrochemically active surface area of the electrode, mainly due to carbon corrosion. Recently, Ohkuma et al. [15] reported the electrode performance for ORR and OER on carbon air electrodes for the aqueous lithium-air cell, where a saturated aqueous solution of $\mathrm{LiOH}$ with $10 \mathrm{M} \mathrm{LiCl}$ was used as the electrolyte, because the LATP protective layer for the water-stable lithium metal electrode is unstable in saturated $\mathrm{LiOH}$ aqueous solution [9]. Steady electrode performance for ORR was observed on high surface area carbon black (Ketjen Black) at $2.0 \mathrm{~mA} \mathrm{~cm}^{-1}$ and at room temperature. The overpotential for OER was slightly higher than that for ORR and gradually increased with the polarization period. Analysis of the gas in the cell after polarization above ca. $0.4 \mathrm{~V}$ vs. NHE revealed the evolution of a small amount of CO during OER by the decomposition of carbon in the electrode. Decomposition of carbon during the charging process was also observed for the non-aqueous lithium-air cell [6]. Thus, suppression of carbon decomposition during the discharge process is one of the most important issues to develop an acceptable rechargeable lithium-air battery for EV. Stevens et al. [16, 17] proposed the use of a third auxiliary electrode for OER made from a metallic grid for aqueous lithium-air batteries. The cell exhibited good cycling behavior for a short discharge and charge period at $2.0 \mathrm{~mA} \mathrm{~cm}^{-2}$. Visco et al. [18] have demonstrated large discharge capacity in a 
primary aqueous lithium-air cell. It is important to examine the possibility for oxidation of the reaction product of $\mathrm{LiOH} \cdot \mathrm{H}_{2} \mathrm{O}$ on the carbon air electrode after deep discharge using the third electrode. The solubility of $\mathrm{LiOH}$ in water is $22.6 \mathrm{~g}$ in $100 \mathrm{~g}$ of water at $20{ }^{\circ} \mathrm{C}$ and the reaction product of $\mathrm{LiOH}$ is precipitated in the electrolyte and/or on the carbon electrode at 5\% discharge depth. Stevens et al. [17] proposed to use an anion exchange membrane to precipitate the reaction product in the electrolyte. In this study, we investigate the deep charge and discharge performance of an aqueous lithium-air cell with an OER electrode, where a high surface area carbon black air electrode without a catalyst was discharged to $2000 \mathrm{mAh} \mathrm{g}_{\text {cathode }}{ }^{-1}$ in the aqueous electrolyte with saturated $\mathrm{LiOH}$ with $10 \mathrm{M} \mathrm{LiCl}$, and charged using the $3^{\text {rd }}$ electrode for OER.

\section{Experimental}

The air electrodes consist of a reaction layer and an air diffusion layer. The reaction layer was prepared by mixing Ketjen black (KB; EC600JD, Akzo Noble; specific surface area of $1400 \mathrm{~m}^{2} \mathrm{~g}^{-1}$ ) and polytetrafluoroethylene (PTFE) in water using ultrasonication. The weight ratio of KB:PTFE was 85:15. The mixture was dried at $80{ }^{\circ} \mathrm{C}$ and pressed onto a Ti mesh (100 mesh) with a carbon paper gas diffusion layer of

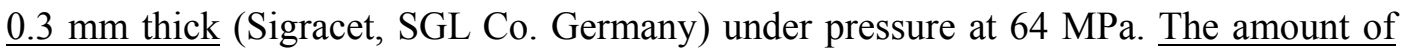
$\underline{\mathrm{KB} \text { was about } 30 \mathrm{mg} \text { for the cell with a limited amount of water, and about } 5 \mathrm{mg} \text { for the }}$ cycling test cell with excess water. The oxygen evolution electrode was prepared by pressing $\mathrm{RuO}_{2}$ powder (Wako Chemicals, Japan; particle size of 1-3 $\mu \mathrm{m}$ ) onto the Ti mesh (100 mesh) under pressure at $128 \mathrm{MPa}$. The thickness of the electrode was about $0.45 \mathrm{~mm}$. LATP plates (19 $\mathrm{mm}$ diameter and $0.15 \mathrm{~mm}$ thick) were purchased from Ohara Inc., Japan.

Figure 1 shows a schematic diagram of the aqueous lithium-air test cell with the oxygen evolution electrode. The diameters of the air electrode and the oxygen evolution electrode were $12 \mathrm{~mm}$ and $10 \mathrm{~mm}$, respectively. The contact area of the air electrode with the electrolyte was $0.50 \mathrm{~cm}^{2}$. LATP was used as the protective layer of the lithium electrode. A conventional non-aqueous electrolyte consisting of a mixture of ethylene carbonate (EC) and diethylene carbonate (DEC) $(1: 1 \mathrm{v} / \mathrm{v})$ with $\mathrm{LiClO}_{4}$ was used as the interlayer to prevent the direct contact of lithium metal with LATP, because LATP is unstable in contact with lithium metal. The amount of the electrolyte used was $c a .2 \mathrm{~mL}$ and the distance between the lithium metal and LATP was $2.0 \mathrm{~cm}$ to prevent direct contact and lithium dendrite growth toward LATP. Sufficient air was supplied using an air pump with a flow rate of $70 \mathrm{~mL} \mathrm{~min}^{-1}$. In some cases, air passed through a $\mathrm{CO}_{2}$ absorber (soda lime) or pure oxygen were used. 
The electrode potentials at a constant current drain were measured using a potentiostat/galvanostat (Hokuto Denko, HJ-10015D8), where a platinum plate with a platinum black or $\mathrm{Hg} / \mathrm{HgO}$ was used as the reference electrode. The cell impedances were measured using an impedance/grain phase analyzer (Solartron, 1260) in the frequency range from $0.1 \mathrm{~Hz}$ to $1 \mathrm{M} \mathrm{Hz}$. Linear sweep voltammetry (LSV) was conducted using a potentiostat/galvanostat (Solatron 1287). The reaction product was examined by X-ray diffraction analysis (XRD, Rigaku, RINT 2500) with $\mathrm{Cu} \mathrm{K} \alpha$ radiation.

\section{Results and discussion}

Figure 2 shows an air electrode polarization curve of the $\mathrm{Li} / 1 \mathrm{M} \mathrm{LiClO}_{4}$ in EC-DEC/LATP/saturated $\mathrm{LiOH}$ with $10 \mathrm{M} \mathrm{LiCl}$ aqueous solution/KB/air cell at $0.88 \mathrm{~mA}$ $\mathrm{cm}^{-2}$ and $25^{\circ} \mathrm{C}$ under an atmospheric air flow, where the mass of $\mathrm{KB}$ and water were $0.0255 \mathrm{~g}$ and $1.54 \mathrm{~g}$, respectively. The air electrode potentials were measured using a platinum plate with a platinum black reference electrode. A steady electrode potential was obtained for $240 \mathrm{~h}$ and then decreased gradually with the polarization period. Considering that the capacity of the lithium-air batteries is always proportional to the area of the air electrode exposed to air, the capacity of the lithium-air batteries is proportional to both the specific capacity per gram of carbon $\left(\mathrm{mAh} \mathrm{gcarbon}^{-1}\right)$ and the carbon loading per area $\left(\mathrm{g}_{\text {carbon }} \mathrm{cm}^{-2}\right)$. Therefore, the product of these two parameters (i.e. area specific capacity $\mathrm{mAh} \mathrm{cm}^{-2}$ ) can be used as a more practical parameter to optimize the performance of the air electrode used in practical lithium-air cells [19]. The area specific capacity was calculated to be $204 \mathrm{mAh} \mathrm{cm}^{-2}$ from the carbon weight capacity of $8000 \mathrm{mAh} \mathrm{g}_{\text {cathode }}{ }^{-1}$ and the carbon loading of $0.0255 \mathrm{~g}_{\text {carbon }} \mathrm{cm}^{-2}$. The area specific capacity is one order higher than that of the $\mathrm{KB}$ oxygen electrode of the non-aqueous lithium-oxygen cell with EC-propylene carbonate (PC)-LiPF 6 [20], where the specific capacities were $5813 \mathrm{~mA} \mathrm{~g}_{\text {carbon }^{-1}}$ and $11 \mathrm{mAh} \mathrm{cm}^{-2}$ at $0.1 \mathrm{~mA} \mathrm{~cm}^{-2}$. Jung et al. [21] reported good cyclability for lithium-oxygen cells with a tetra(ethylene) glycol dimethyl-lithium triflate electrolyte and a high specific capacity of $5000 \mathrm{~mA}$ gcarbon $^{-1}$; however, the area specific capacity was as low as $5 \mathrm{mAh} \mathrm{cm}^{-2}$. The high area specific capacity of the air electrode in the aqueous system is one of the advantages of the aqueous lithium-air system over the non-aqueous system. Figure 3 shows an optical micrograph and XRD pattern of the air electrode after discharge at $0.88 \mathrm{~mA} \mathrm{~cm}^{-2}$ for $240 \mathrm{~h}$. A needle-like reaction product was observed, which was confirmed to be $\mathrm{LiOH} \cdot \mathrm{H}_{2} \mathrm{O}$ from the XRD pattern. The high area specific capacity of the $\mathrm{KB}$ electrode in aqueous solution may be due to the formation of the well-crystallized needle-like 
reaction product, which could keep the active electrode reaction points under a deep discharge depth. Figure 4 shows the KB electrode potential for OER and ORR vs. current density curves in the saturated aqueous solution of $\mathrm{LiOH}$ with $10 \mathrm{M} \mathrm{LiCl}$ at $25{ }^{\circ} \mathrm{C}$, where the electrode potentials were recorded after $10 \mathrm{~min}$ polarization at each current density using a $\mathrm{Hg} / \mathrm{HgO}$ reference electrode under an air flow. The open-circuit voltage $(\mathrm{OCV}$ ) of the electrode was $5.7 \mathrm{mV}$ vs. $\mathrm{Hg} / \mathrm{HgO}$. The overpotentials for ORR and OER at $7.8 \mathrm{~mA} \mathrm{~cm}^{-2}$ were 560 and $295 \mathrm{mV}$, respectively. The overpotential for OER is higher than that for ORR. The overpotentials in the aqueous electrolyte are lower than those in non-aqueous electrolytes, which may be due to higher solubility of oxygen and the reaction products in the aqueous electrolyte than in the non-aqueous electrolytes. The summation of the overpotentials for OER and ORR of $1.0 \mathrm{~V}$ at $7.8 \mathrm{~mA}$ $\mathrm{cm}^{-2}$ is attractive, but should be reduced more for EV applications.

The change in the air electrode potential for ORR and OER of the lithium-air cell with a limited amount of water in the aqueous electrolyte was examined. Figure 5 shows air electrode potential vs. capacity curves for the $\mathrm{Li} / \underline{1 \mathrm{M} \quad \mathrm{LiClO}_{4}}$ in

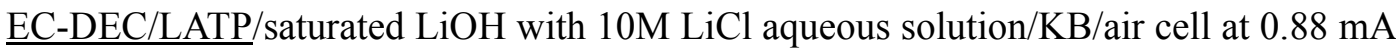
$\mathrm{cm}^{-2}$ and $25^{\circ} \mathrm{C}$, where the electrode potentials were measured using a platinum with a platinum black reference electrode. The amount of loaded water (active material) and $\mathrm{KB}$ were 0.305 and $0.0255 \mathrm{~g}$, respectively. The theoretical capacity of water is calculated to be $993 \mathrm{~mA} \mathrm{~h} \mathrm{~g}-\mathrm{H}_{2} \mathrm{O}^{-1}$ using the following cell reaction:

$$
4 \mathrm{Li}+6 \mathrm{H}_{2} \mathrm{O}+\mathrm{O}_{2}=4 \mathrm{LiOH} \cdot \mathrm{H}_{2} \mathrm{O}
$$

The cell was discharged up to $300 \mathrm{~mA}$ g- $\mathrm{H}_{2} \mathrm{O}^{-1}$, which corresponds to $30 \%$ discharge depth for the capacity of the loaded water, and then charged, where the KB air electrode

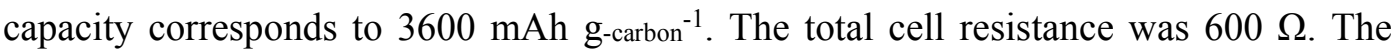
main part of the cell resistance comes from the resistances of the LATP plate and the 1 $\mathrm{M} \mathrm{LiClO}_{4}$ in EC-DEC electrolyte. A steady state discharge cell voltage is observed. On the other hand, the initial overpotentials for OER are low and then gradually increase up to $1000 \mathrm{mV}$. The overpotentials for the ORR at the second cycle were too high and could not discharge at $0.88 \mathrm{~mA} \mathrm{~cm}^{-2}$. The high overpotential for the OER after polarization for a long period could be explained by the decomposition of carbon in the saturated aqueous solution of $\mathrm{LiOH}$ with $10 \mathrm{M} \mathrm{LiCl}$, as observed by Okuma et al. [14] and for a solution of tetraglyme with LiPF6 by Thotiyl et al. [6]. The cell with the $3^{\text {rd }}$ metal grid electrode for the OER was proposed by Stevens et al. [17] to avoid the use of a carbon electrode for the OER. Figure 6 shows typical charge and discharge curves at 
$25{ }^{\circ} \mathrm{C}$ for the $\mathrm{Li} / \underline{1 \mathrm{M} \mathrm{LiClO}} 4$ in EC-DEC/LATP/saturated $\mathrm{LiOH}$ with $10 \mathrm{M} \mathrm{LiCl}$ aqueous solution/KB/air cell with the platinum and platinum black $3^{\text {rd }}$ electrode, where the current densities for discharge and charge were 0.88 and $1.0 \mathrm{~mA} \mathrm{~cm}{ }^{-2}$, respectively. The loaded water and KB were 0.305 and $0.0255 \mathrm{~g}$, respectively. Steady discharge and charge cell voltages were observed, but the cell voltages for charging were as high as $c a$. 4.5 V. The high cell voltage for charging may be due to the poor catalytic activity of platinum for OER at room temperature in the saturated aqueous solution of $\mathrm{LiOH}$ with $10 \mathrm{M} \mathrm{LiCl}$ and the high cell resistance of $600 \Omega$. We have examined the catalytic activity of various electrodes for OER in the saturated aqueous solution of $\mathrm{LiOH}$ with $10 \mathrm{M} \mathrm{LiCl}$. The electrode should be stable in the aqueous solution with a high concentration of chloride ions and with $\mathrm{pH}$ of around 9. Metal electrodes such as $\mathrm{Ag}$ and $\mathrm{Ni}$, which exhibit excellent catalytic activity for OER in alkaline solutions [22, 23], were unstable in the solution with $\mathrm{LiCl}$. The selected stable oxides in the solution were pressed on the Ti mesh (100 mesh) with the $4 \mathrm{wt} \%$ PTFE binder and 0-50 vol\% Ti powder (Koujundkagaku, Japan; 15-30 $\mu \mathrm{m}$ particle size) and the catalytic activity for OER was compared using LSV. Figure 7 shows LSV curves for various oxide electrodes of $\mathrm{RuO}_{2}$, $\mathrm{NiCo}_{2} \mathrm{O}_{4}, \quad \varepsilon-\mathrm{MnO}_{2}$ and $\mathrm{La}_{0.6} \mathrm{Sr}_{0.4} \mathrm{Co}_{0.2} \mathrm{Fe}_{0.8} \mathrm{O}_{3}$ (LSCF; Seimichemicals, Japan). The highest catalytic activity for OER was observed for $\mathrm{RuO}_{2}$ in the saturated $\mathrm{LiOH}$ aqueous solution with $10 \mathrm{M} \mathrm{LiCl} . \mathrm{RuO}_{2}$ has high metal-like conductivity at room temperature and titanium coated with $\mathrm{RuO}_{2}$ and $\mathrm{TiO}_{2}$ is known as a dimensionally stable anode (DSA) for industrial chlorine production cells [24]. Recently, Yilmaz et al. reported an excellent catalytic activity of $\mathrm{RuO}_{2}$ dispersed on carbon nanotubes for OER in the non-aqueous lithium-oxygen cells [25]

The long term stability of the $\mathrm{RuO}_{2}$ on Ti mesh electrode was tested as the $3^{\text {rd }}$ electrode for OER in the proposed aqueous lithium-air cell. Figure 8 shows the cyclic performance of the $\mathrm{Li} / 1 \mathrm{M} \mathrm{LiClO}_{4}$ in EC-DEC/LATP/saturated $\mathrm{LiOH}$ and 10

$\mathrm{M} \mathrm{LiCl}$ aqueous solution/KB/air cell at $0.64 \mathrm{~mA} \mathrm{~cm}^{-2}$ and $25^{\circ} \mathrm{C}$, where the weight of the loaded $\mathrm{KB}$ on the air electrode was $0.0042 \mathrm{~g}$ and the cell was discharged to the

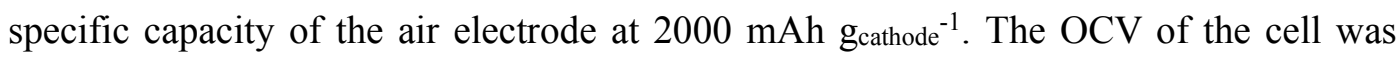
$2.98 \mathrm{~V}$ at $25{ }^{\circ} \mathrm{C}$, which is comparable to that reported previously for the aqueous lithium-air cell with saturated $\mathrm{LiCl}$ and $\mathrm{LiOH}$ aqueous solution [26]. Steady cell voltages for the charge and discharge processes were observed for three cycles. The overpotentials for charging are higher than those for discharging. The energy loss of the charge and discharge processes due to the overpotentials is approximately $43 \%$, but the loss could be reduced by reducing the resistance of the electrolyte. At the $5^{\text {th }}$ cycle, the discharge cell voltages decreased significantly to $1.57 \mathrm{~V}$ after discharge for $7 \mathrm{mAh}(14 \mathrm{~h}$ 
discharge and $75 \mathrm{~h}$ total operation times). A steady discharge cell voltage of $1.57 \mathrm{~V}$ was observed for further cycling, and the cell voltage for charging had almost the same behavior with cycling. Cell impedance profiles of before cycling and the discharged state after the $7^{\text {th }}$ cycle were not significantly different, as shown in Fig. 9. The seven times cycled air electrode was washed in water and the discharge performance was then tested; the electrode performance was recovered by washing. The surface may be covered with a material that is soluble in water, but insoluble in saturated $\mathrm{LiOH}$ with 10 $\mathrm{M} \mathrm{LiCl}$. Figure 10 shows the discharge performance of a fresh $\mathrm{Li} / \underline{1 \mathrm{M} \mathrm{LiClO}} 4$ in EC-DEC / LATP/saturated $\mathrm{LiOH}$ with $10 \mathrm{M} \mathrm{LiCl}$ aqueous solution/KB cell without an air supply at $0.64 \mathrm{~mA} \mathrm{~cm}^{-2}$ and $25^{\circ} \mathrm{C}$. The cell showed a high voltage of around $2.5 \mathrm{~V}$ for a short initial period and then a steady cell voltage of around $1.5 \mathrm{~V}$ for a long period. The cell reaction without oxygen could be given as:

$$
2 \mathrm{Li}+2 \mathrm{H}_{2} \mathrm{O}=2 \mathrm{LiOH}+\mathrm{H}_{2}
$$

The calculated cell voltage at $\mathrm{a}_{\mathrm{H} 2}=1$ and $25^{\circ} \mathrm{C}$ is $1.68 \mathrm{~V}$, where the $\mathrm{pH}$ of the saturated aqueous solution of $\mathrm{LiOH}$ with $10 \mathrm{M} \mathrm{LiCl}$ was 9 [27]. Considering the overpotential for discharge at $0.64 \mathrm{~mA} \mathrm{~cm}^{-1}$, the discharge cell voltage of $1.5 \mathrm{~V}$ could be explained by reaction (2); the evolution of hydrogen gas was detected during the discharge process by a gas chromatogram. The steady cell voltage at $1.57 \mathrm{~V}$ after the $7^{\text {th }}$ cycle may be due to reaction (2), where the air supply was suppressed by an insoluble material covering the $\mathrm{KB}$. A candidate for the insoluble material is $\mathrm{Li}_{2} \mathrm{CO}_{3}$, which is produced by the reaction of $\mathrm{LiOH}$ and $\mathrm{CO}_{2}$ in air. The cyclic performance of the cell was improved by passing air through a tube with soda lime to remove $\mathrm{CO}_{2}$. These results suggest that the degradation of the cell performance could be explained by contamination with $\mathrm{CO}_{2}$ in the air. The surface of the $\mathrm{KB}$ electrode may be covered with $\mathrm{Li}_{2} \mathrm{CO}_{3}$ and the air electrode performance was degraded during the operation period. The $\mathrm{Li} / 1 \mathrm{M} \mathrm{LiClO}_{4}$ in $\mathrm{EC}-\mathrm{DEC}$ /LATP/saturated $\mathrm{LiOH}$ with $10 \mathrm{M} \mathrm{LiCl}$ aqueous solution/KB/oxygen cell was operated under pure oxygen flow and the cycling performance at $0.64 \mathrm{~mA} \mathrm{~cm}{ }^{-2}$ and $25{ }^{\circ} \mathrm{C}$ are shown in Fig. 11, where the weight of KB was $0.0040 \mathrm{~g}$ and an excess amount of water was loaded. The cell was discharged to the specific capacity of the air electrode at 2000 $\mathrm{mAh} \mathrm{g}_{\text {cathode }}{ }^{-1}$. Good cyclic performance was observed until the $8^{\text {th }}$ cycle and the discharge cell voltage was then gradually decreased with cycling. The reason for the degradation in the discharge performance is not clear at present, although a possible reason may be the poor cyclability of the lithium electrode. Much fine lithium powder was observed in the $1 \mathrm{M} \mathrm{LiClO}_{4}$ in EC-DEC electrolyte, which suggests lithium dendrite 
formation in the liquid electrolyte [28]. The polymer electrolyte suppresses lithium dendrite formation at a lower current density, but at high current densities such as $1 \mathrm{~mA}$ $\mathrm{cm}^{-2}$, lithium dendrite formation was observed for short period polarization [29]. However, the lithium electrode potentials measured using the $\mathrm{RuO}_{2}$ electrode at the $10^{\text {th }}$ cycle showed a steady potential of $2.5 \mathrm{~V}$. Therefore, the degradation of the cell performance by cycling could not be explained by the poor cyclability of the lithium electrode. The other possibility for the degradation of the discharge performance at the $9^{\text {th }}$ or greater cycles may be a degradation of the oxygen reduction catalytic activity of $\mathrm{KB}$ by the deposition and dissolution of $\mathrm{LiOH} \cdot \mathrm{H}_{2} \mathrm{O}$ on the $\mathrm{KB}$ surface and/or be a decrease of active area for ORR by a reminded $\mathrm{LiOH} \cdot \mathrm{H}_{2} \mathrm{O}$ on KB. Thus, a continued search for excellent ORR catalysts and carbon electrode and also the suppression of lithium dendrite formation are important further research items for the realization of aqueous lithium-air batteries.

\section{Conclusion}

An aqueous lithium-air cell of $\mathrm{Li} / 1 \mathrm{M} \mathrm{LiClO}_{4}$ in EC-DEC/LATP/saturated $\mathrm{LiOH}$ with $10 \mathrm{M} \mathrm{LiCl}$ aqueous solution/KB/air with a $3^{\text {rd }}$ electrode for OER was proposed. Successful charge and discharge performance was observed at $0.64 \mathrm{~mA} \mathrm{~cm}{ }^{-1}$ and $25{ }^{\circ} \mathrm{C}$ for several cycles. The specific energy density calculated from the mass of lithium, oxygen, carbon, and water is $810 \mathrm{Wh} \mathrm{kg}^{-1}$. The calculated specific energy density is approximately twice that of a conventional lithium-ion battery and comparable with that of an aqueous lithium-air cell with an acetic acid electrolyte operated at $60{ }^{\circ} \mathrm{C}$ and $3 \mathrm{~atm}$ [30]. The cell performance was degraded by cycling more than 5 cycles under air. The degradation was lessened under pure oxygen, but the discharge performance was still slightly degraded after the $9^{\text {th }}$ cycle. An energy loss of $c a .30 \%$ at $0.64 \mathrm{~mA} \mathrm{~cm}^{-1}$ by the overpotential for the OER and ORR is considerably lower than that for the non-aqueous system, but should be improved for the practical application of aqueous lithium-air batteries for EVs.

\section{Acknowledgment}

This work was supported by the Japanese Science and Technology Agency (JST) under the "Advanced Low Carbon Technology and Development Program". 


\section{References}

[1] P.G. Bruce, S.A. Freunberger, L.J. Hardwick, J.M. Tarascon, Nat. Mater., 11 (2012) 19

[2] T. Zhang, N. Imanishi, Y. Takeda, O. Yamamoto, Chem. Lett. 40 (2011) 669

[3] S.A. Freunberger, Y. Chen, Z. Peng, J.M. Griffin, L.J. Hardwick, F. Bard, P.G. Bruce, J. Am. Chem. Soc., 133 (2011) 8040

[4] A. Debart, A.J. Paterson, J. Bao, P.G. Bruce, Angew. Chem. Int. Ed. 47 (2008) 4521

[5] M. Armand, J.-M. Tarascon, Nature, 451 (2008) 652

[6] M.M.O. Thotiyl, S.A. Freunberger, Z. Peng, P.G. Bruce, J. Am. Chem. Soc., 135 (2013) 494

[7] S.J. Visco, E. Nimon, B. Katz, L. Johne M. Chu, 12 ${ }^{\text {th }}$ International Meeting on Lithium Batteries, Nara, Japan, Abst. \# 53 (2004)

[8] N. Imanishi, S. Hasegawa, T. Zhang, A. Hirano, Y. Takeda, O. Yamamoto, J. Power Sources, 185 (2008) 1392

[9] S. Hasegawa, N. Imanishi, T. Zhang, J. Xia, A. Hirano, Y. Takeda, O. Yamamoto, J. Power Sources, 189 (2009) 371

[10] T. Zhang, N. Imanishi, A. Hirano, Y. Takeda, O. Yamamoto, Electrochem. Solid State Lett., 14 (2011) A45

[11] Y. Wang, H. Zhou, J. Power Sources, 195 (2010) 348

[12] L. Ojefors, L. Carsson, J. Power Sources, 8 (1977/1978) 287

[13] V. Nedurchilov, H. Wang, J.M. Martin, W. Qu, J. Power Sources, 195 (2010) 1271

[14] H. Arai, S. Muller, O. Hase, J. Electrochem. Soc., 147 (2000)3584

[15] H. Ohkuma, I. Uechi, M. Matsui, Y. Takeda, O. Yamamoto, N. Imanishi, J. Power Sources, 245 (2014) 90

[16] P. Stevens, G. Toussaint, G. Gaillo, P. Viaud, P. Vinatier, C. Cantau, O. Ficher, C. Sarrazin, M. Mallouki, ECS Transactions, 28 (32) (2010) 1

[17] P. Stevens, G. Toussaint, L. Puech, P. Viantier, ECS Trans., 50 (15) (2013) 1

[18] S.J. Visco, Advance workshop, Lawrence Berkeley National Laboratory, Berkeley, CA (2004)

[19] J. Xiao, J. Electrochem. Soc., 157 (2010) A487

[20] S.D. Beatils, D.M. Manolesue, S.L. Blair, J. Electrochem, Soc., 156 (2009) A44

[21] H.-G. Jung, J. Hassoun, J.-B. Park, Y.-K. Sun, B. Scrosati, Nat. Mater., 4, (2012) 579

[22] P. Fischer, J. Heitham, J. Electroanal. Chem., 112 (1980) 231

[23] L. Carlsson, L. Ojefors, J. Electrochem. Soc., 127 (1980) 525

[24] S. Trasatti, Electrochim. Acta, 45 (2000) 2377 
[25] E.Yilmaz, C Yogi, K. Yamanaka, T. Ohta, H.R. Byon, Nano Lett., 13 (2013) 4679

[26] N. Imanishi, O. Yamamoto, in B. Scrosati et al. (eds) Lithium batteries, Advance technology and applications, John Wiley and Son, Hoboken, NJ, 2013, pp. 212-232

[27] Y. Shimonishi, T. Zhang, N. Imanishi, D. Im, D.-J. Lee, A. Hirano, Y. Takeda, O. Yamamoto, N. Sammes, J. Power Sources, 196 (2011) 5128

[28] E. Pelet, J. Electrochem. Soc., 126 (1979) 2047

[29] S. Liu, H. Wang, N. Imanishi, T. Zhang, A. Hirano, Y. Takeda, O. Yamamoto, J. Yang, J. Power Sources, 196 (2011) 7681

[30] T. Zhang, N. Imanishi, Y. Shimonishi, A. Hirano, A. Takeda, O. Yamamoto, N. Sammes, Chem. Commun. 46 (2010) 1661 


\section{Figure captions}

Fig. 1. Schematic diagram of the test cell.

Fig. 2. Discharge curve of the $\mathrm{Li} / 1 \mathrm{M} \mathrm{LiClO}_{4}$ in EC-DME/LATP/saturated $\mathrm{LiOH}$ with $10 \mathrm{M} \mathrm{LiCl} / \mathrm{KB}$, air cell at $0.88 \mathrm{~mA} \mathrm{~cm}^{-2}$ and room temperature.

Fig. 3. (a) XRD patterns and (b) optical microscope image of the air electrode after discharged at $0.88 \mathrm{~mA} \mathrm{~cm}^{-2}$ for $240 \mathrm{~h}$.

Fig. 4. Current density vs. oxygen evolution and reduction polarization curves for KB electrode in saturated $\mathrm{LiOH}$ with $10 \mathrm{M} \mathrm{LiCl}$ aqueous solution at room temperature.

Fig. 5. Air electrode potential vs. capacity curves of the $\mathrm{Li} / 1 \mathrm{M} \mathrm{LiClO}_{4}$ in EC-DEC/LATP/saturated LiOH with $10 \mathrm{M} \mathrm{LiCl} / \mathrm{KB}$, air cell at $0.88 \mathrm{~mA} \mathrm{~cm}{ }^{-2}$ and $25^{\circ} \mathrm{C}$ using a platinum plate with a platinum black reference electrode.

Fig. 6. Charge and discharge curves of the $\mathrm{Li} / 1 \mathrm{M} \mathrm{LiClO}_{4}$ in EC-DEC/LATP/saturated $\mathrm{LiOH}$ with $10 \mathrm{M} \mathrm{LiCl} / \mathrm{KB}$, air cell with the $3^{\text {rd }}$ electrode for OER at $0.64 \mathrm{~mA} \mathrm{~cm}^{-2}$ and $25{ }^{\circ} \mathrm{C}$.

Fig. 7. Liner sweep voltammograms of various electrodes for OER in a saturated aqueous solution of $\mathrm{LiOH}$ with $10 \mathrm{M} \mathrm{LiCl}$ at room temperature. Scan rate $=10 \mathrm{mV} \mathrm{s}^{-1}$;

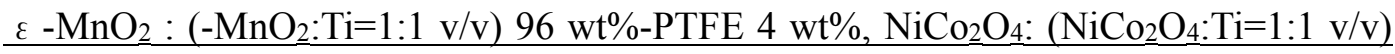
96-PTFE $4 \mathrm{wt} \%$, LSCF: LSCF $76 \mathrm{wt} \%$-Ti $20 \mathrm{wt} \%$-PTFE $4 \mathrm{wt} \%, \mathrm{RuO}_{2}: \mathrm{RuO}_{2} 96$ wt $\%$-PTFE $4 \mathrm{wt} \%$.

Fig. 8. Cyclic performance of the $\mathrm{Li} / 1 \mathrm{M} \mathrm{LiClO}_{4}$ in $\mathrm{EC}-\mathrm{DEC} / \mathrm{LATP} /$ saturated $\mathrm{LiOH}$ with $10 \mathrm{M} \mathrm{LiCl} / \mathrm{KB}$, air cell with the $\mathrm{RuO}_{2} 3^{\text {rd }}$ electrode for charging at $0.64 \mathrm{~mA} \mathrm{~cm}^{-2}$ and $25{ }^{\circ} \mathrm{C}$.

Fig. 9. Impedance profiles of (a) the charged state $\mathrm{KB}$ electrode after the $7^{\text {th }}$ cycle and (b) the pristine $\mathrm{KB}$ electrode at $25^{\circ} \mathrm{C}$.

Fig. 10. Discharge curve for the $\mathrm{Li} / 1 \mathrm{M} \mathrm{LiClO}_{4}$ in EC-DME/LATP/saturated $\mathrm{LiOH}$ with $10 \mathrm{M} \mathrm{LiCl} / \mathrm{KB}$ cell without air at $0.64 \mathrm{~mA} \mathrm{~cm}^{-2}$ and $25^{\circ} \mathrm{C}$.

Fig. 11. Cyclic performance of the $\mathrm{Li} / 1 \mathrm{M} \mathrm{LiClO}_{4}$ in EC-DEC/LATP/saturated $\mathrm{LiOH}$ with $10 \mathrm{M} \mathrm{LiCl}$ aqueous solution/KB cell in $\mathrm{O}_{2}$ at $0.64 \mathrm{~mA} \mathrm{~cm}^{-2}$ and $25^{\circ} \mathrm{C}$. 
Fig.1

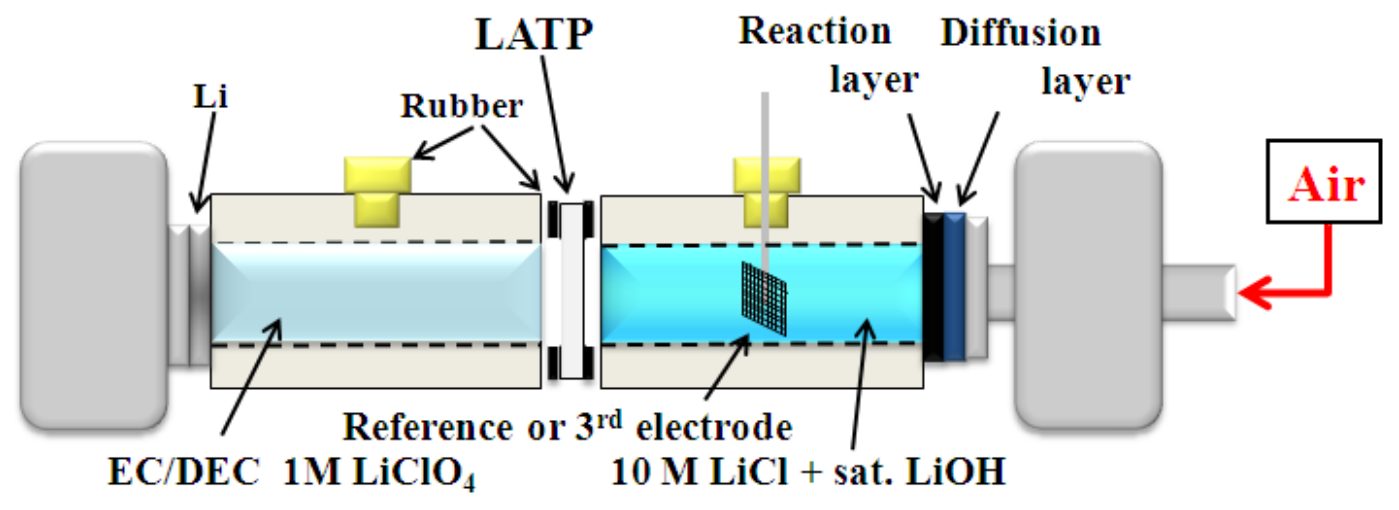


Fig.2

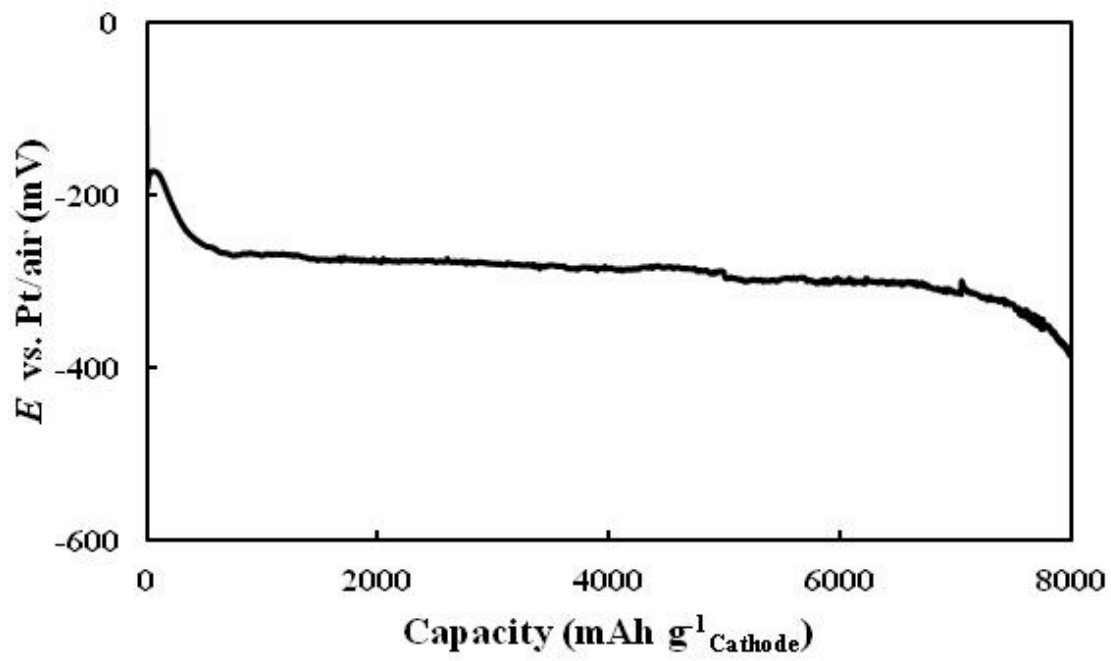


Fig.3
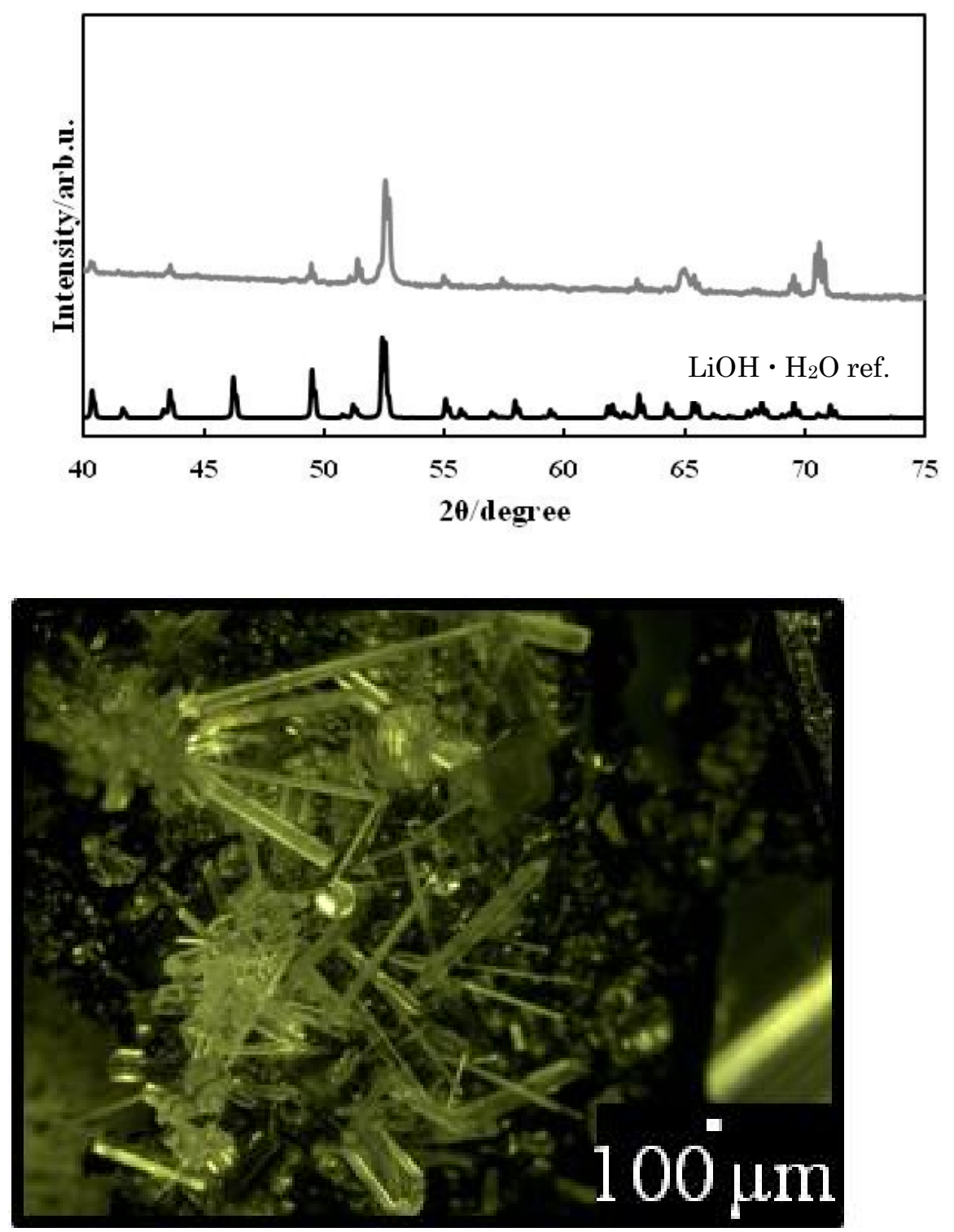
Fig.4

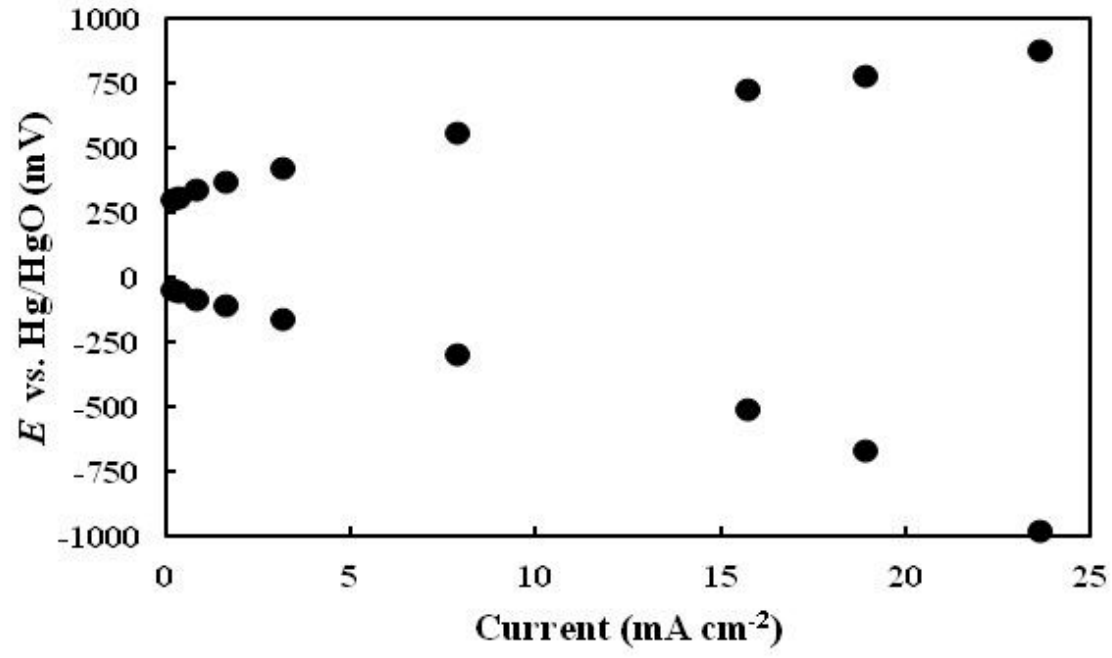


Fig.5

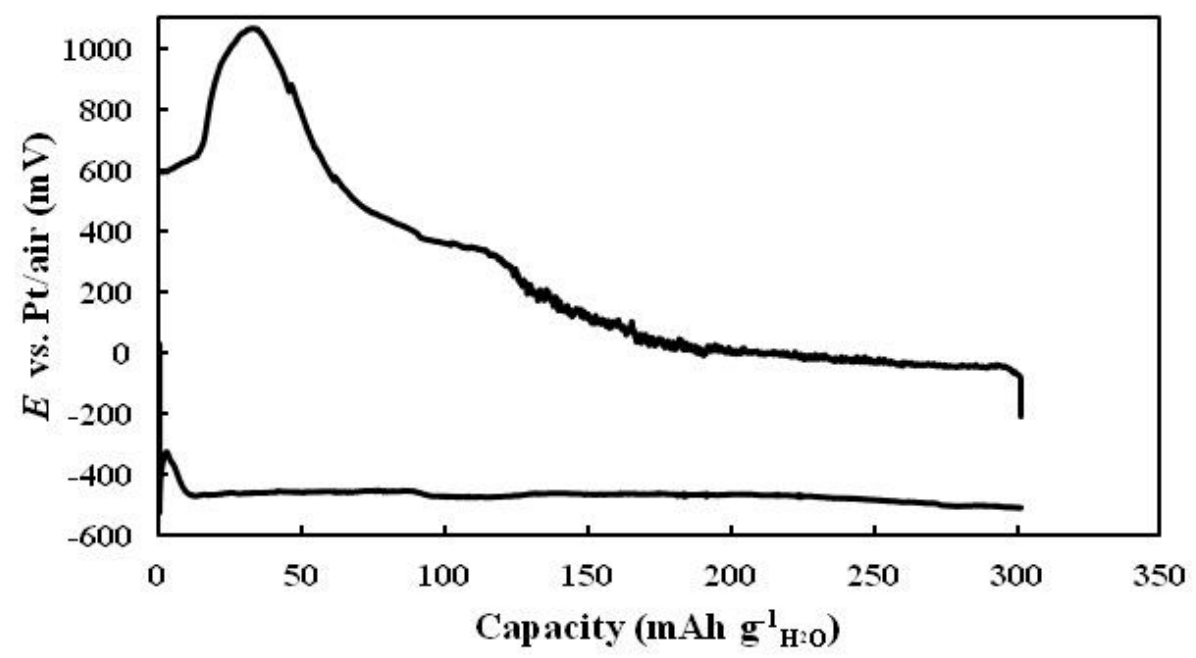


Fig.6

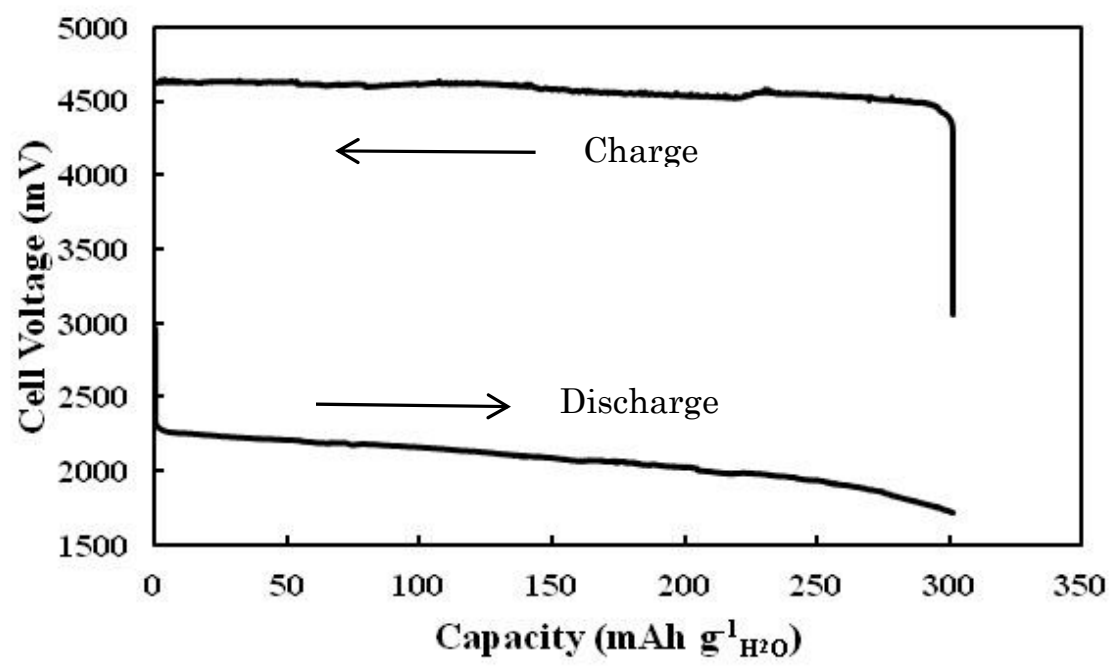


Fig.7

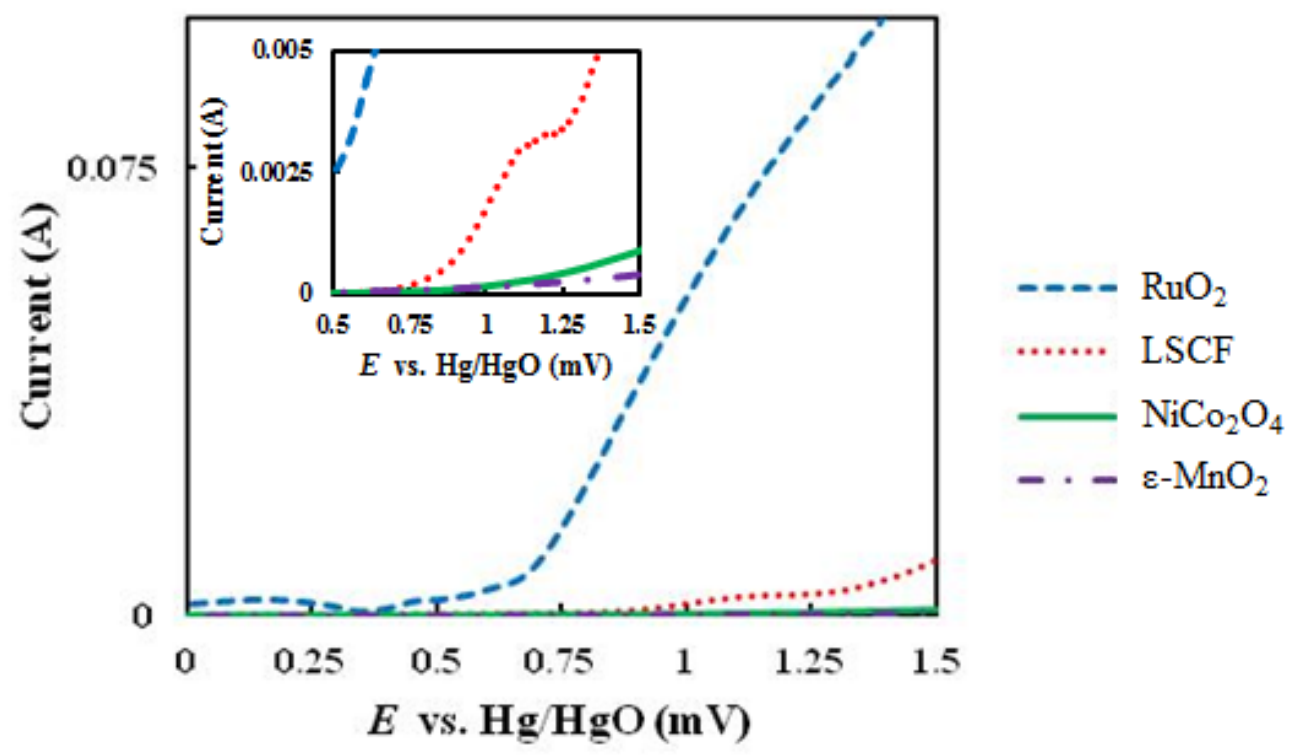


Fig.8

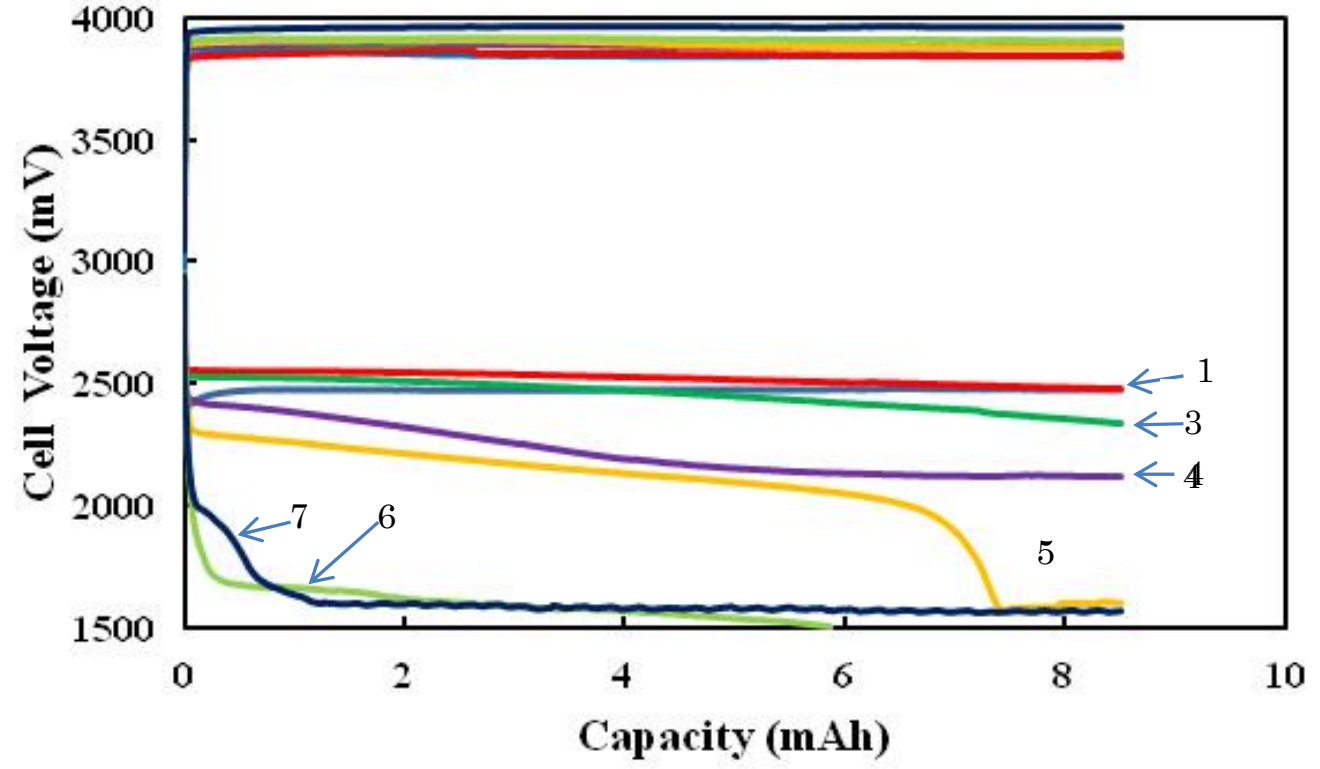


Fig.9
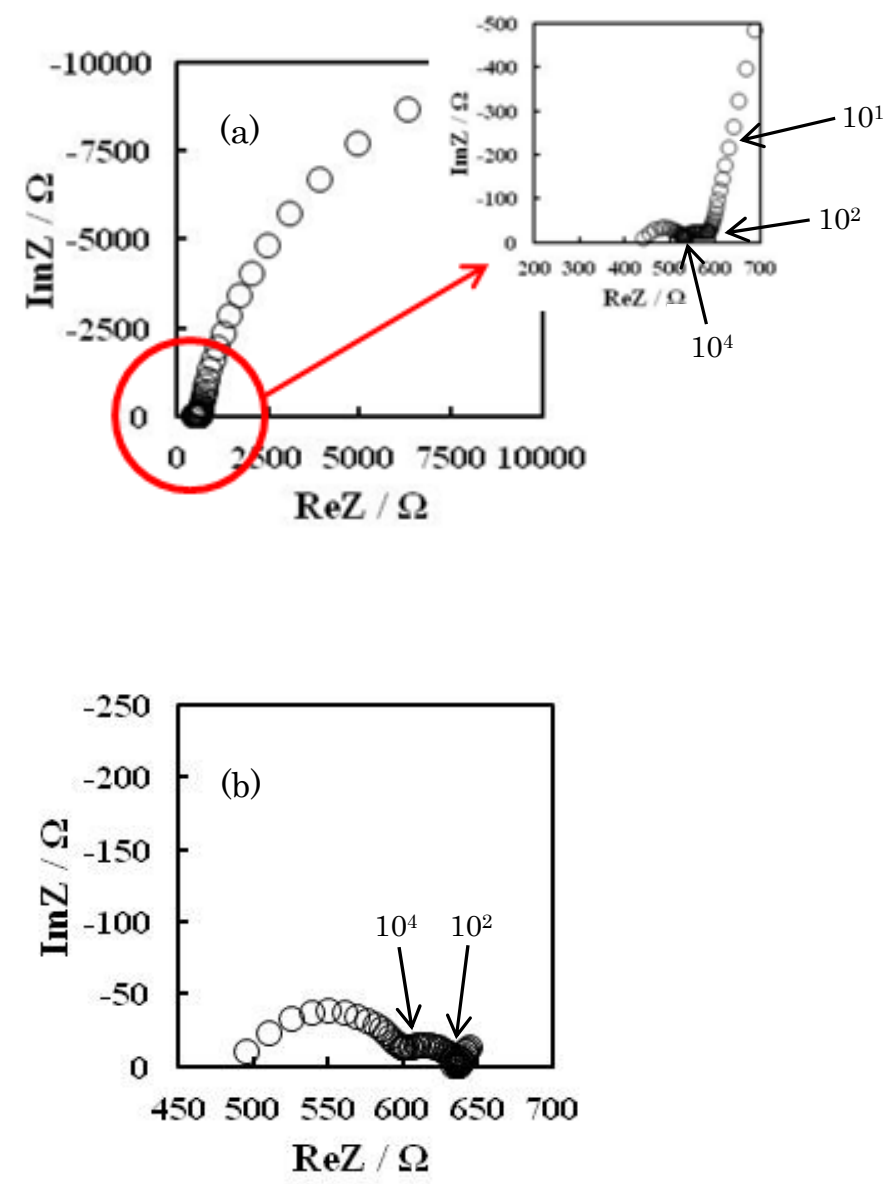
Fig.10

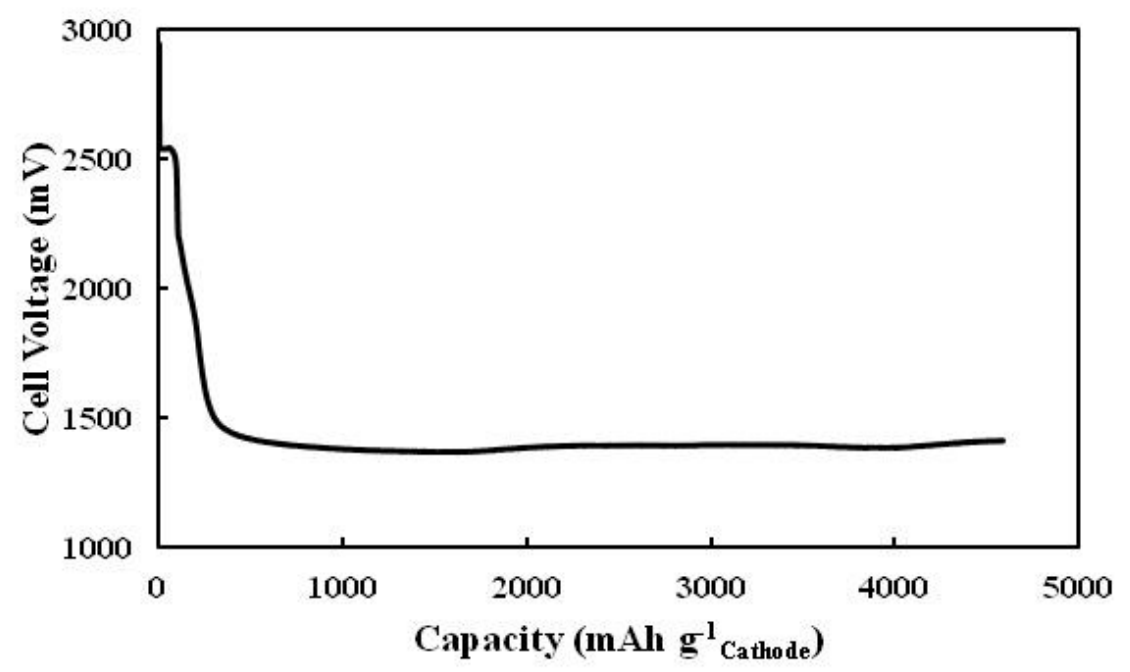


Fig.11

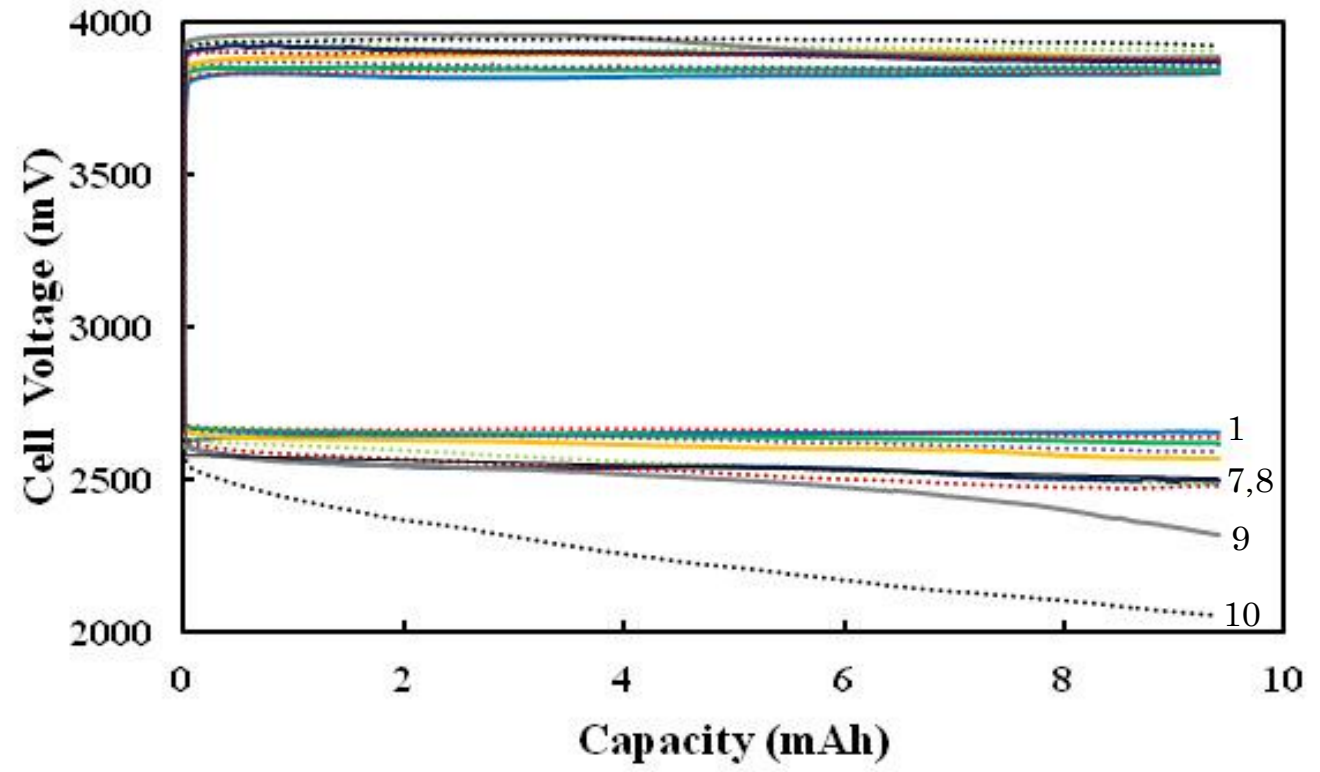

